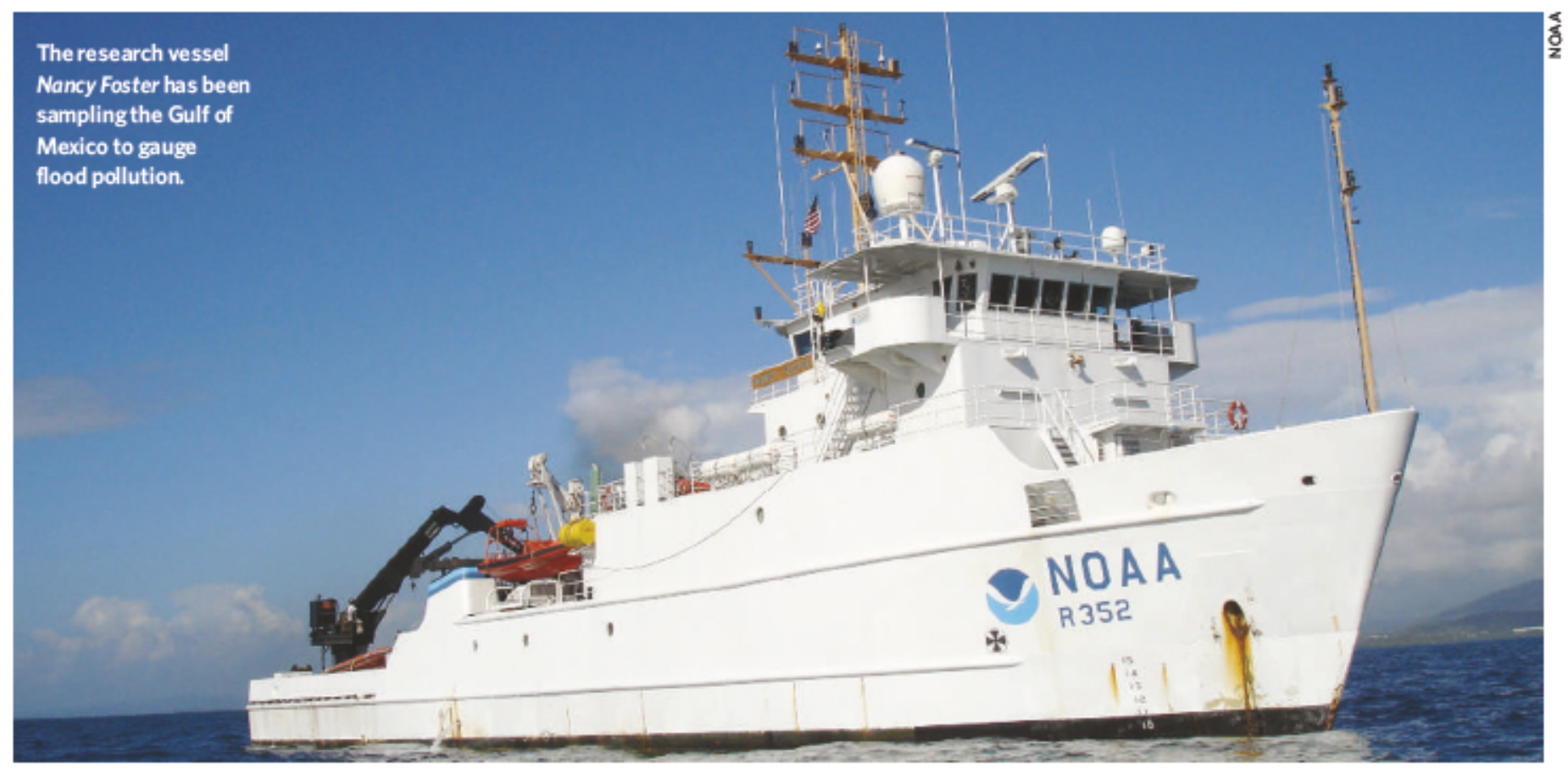

\title{
After Katrina: tracking the toxic flood
}

\section{BATON ROUGE}

Three weeks after Hurricane Katrina ravaged the coasts of Mississippi and Louisiana, marine researchers are starting to assess the safety of fish and shellfish exposed to toxic flood waters in the Gulf of Mexico.

The flood waters are teeming with Escherichia coli bacteria and a wide range of chemicals (see Nature 437, 301; 2005). And engineers are pumping the toxic mix out of the city towards the Gulf coast. With its shrimp, oyster, crab and flat-fish stocks valued at around $\$ 3.1$ billion, the coast is one of the richest fishing grounds in the United States.

Shailer Cummings of the National Oceanic and Atmospheric Administration led a foodsafety team into the Gulflast week for a threeday expedition on board the research vessel Nancy Foster. Until then the boat was being used to check the safety of the region's major ports, doing soundings to check for obstructions under the water, among other tasks.

Cummings had just two days to organize the expedition - a huge challenge under normal circumstances and more so as personnel were in such short supply. "When you try to get a research team from a distressed area they are hungry, stressed and looking for their family like everyone else," he says. So he recruited a team from the Northwest Fisheries Science Center in Seattle, Washington.

His team of some 15 scientists collected shrimp, oysters and Atlantic croakers - a common ground fish - and sent them to a Seattle laboratory to be tested for bacterial contamination and pollutants. Aware of the risk of a second public-health disaster in the wake of the hurricane, the researchers worked around the clock. "Nobody sleeps," Cummings told Nature after three tough days aboard the Nancy Foster. "We're doing this to make sure the food supply is safe."

On their tour through the Gulf, the crew took samples from the muddy plume that has spread from the Louisiana coast over hundreds of square kilometres. Katrina muddied the water by washing sediments from the Mississippi into the sea, explains Cummings. And the fresh water is sitting on top of the salty water, spreading "like tea on a tabletop".

So far, the team has seen no evidence of the algal bloom that might result from the freshwater influx, and the circulation pattern of the water seems normal. But "we don't know what's in the water", says Cummings.

As well as sampling water and sediment for pathogens and chemicals, the researchers dissected, prepared and labelled fish samples for storage until they could be tested back in Seattle. It was close, feverish and smelly work. The liver and bile will be tested for fat-based contaminants such as polyaromatic hydrocarbons. The gut and gill will be tested for pathogens, and the muscle will be tested for mercury and other contaminants.

"It's an unprecedented situation," says Tracy Collier, head of the ship's wet lab and director of Environmental Conservation at the Northwest Fisheries Science Center. "We're trying to sample as broadly as we can," he explains, to detect anything that might harm people.

The results will not be ready until the end of September. But it is unlikely anyone will get ill in the meantime, says Bo Boehringer of the Louisiana Department of Wildlife and Fisheries, because no fishing is likely to take place for many weeks. Katrina has brought the fishing community in the region to a standstill. Boats and piers have been destroyed, ice houses smashed and fish-processing centres damaged. US authorities estimate that about 4,800 fishermen in the area are now out of work.

Although serious attention is being paid to food safety, there is also concern that Katrina has damaged fish and shellfish stocks. Flood water has covered oyster beds along a stretch of inland bays with up to a metre of mud, and the oysters have suffocated.

Some wildlife seems to be bouncing back, however. Biologist Melody Baron was on board the Nancy Foster to watch for marine mammals in distress. On her third 12-hour shift she said she had seen turtles and dolphins behaving normally.

Adrianne Appel 